УДК 811.161 .1

\title{
Semantic Situation and its Representation in the Texts of Different Genres
}

\author{
Tatiana V. Tarasenko ${ }^{a}$ and Enrique F. Quero Gervilla ${ }^{\text {b* }}$ \\ ${ }^{a}$ Siberian State Aerospace University named after M.F. Reshetnev \\ 31 Krasnoyarsky Rabochy, Krasnoyarsk, 660037, Russia \\ ${ }^{b}$ University of Granada \\ Granada, 18071, Spain
}

Received 19.11.2015, received in revised form 27.11.2015, accepted 24.02.2016

In this paper the authors analyzed the semantic situation and its representation in accordance with the text type, namely, urban folklore texts - anecdotes (jokes) and fiction. The authors focused mainly on the situation of wine drinking. The set of actants depends on text nature realized differently in different types of texts. The most comprehensive representation of the wine drinking situation is found in Russian anecdotes: they feature the quantity and quality of the represented predicates and actants. In the literary text the selection of predicates and wine drinking participants is determined by the author's intention.

Keywords: semantic situation, anecdote (joke), literary text, folklore text, wine drinking situation, semantic syntax.

DOI: 10.17516/1997-1370-2016-9-3-646-652.

Research area: philology.

In this paper we decided to consider any situation as a semantic one, namely the situation of wine drinking, reflecting a fragment of reality from the standpoint of semantic syntax. First of all, we were interested in this situation's representations in the language and how it functions in texts of different types.

"Event" or "situation" in linguistics means: sentence's denotation (Gak, 1972, p. 349), “a part of reality" (Nikolaeva, 1980, p. 198), "a fragment of the world", "anything that can be described in a sentence" (Dem'iankov, 1983, p. 324; Dem'iankov, 2004, p. 68), and finally, the "people's world in which the man is the main character" (Kon'kov, 2011, p. 87). According to the semantic approach to the language, reconstruction and research of the linguistic world view is carried out by describing such unit as a semantic situation. Proposition and its actantial content are basic elements of any semantic situation (Shmeleva, 1988).

As research material the authors chose anecdotes (jokes) and extracts from fiction, namely from plays by A.P. Chekhov. This choice was made with a special purpose, in order to analyze the similarities and differences of the

(C) Siberian Federal University. All rights reserved

* Corresponding author E-mail address: tvt2004@mail.ru, efquero@gmail.com 
linguistic embodiment of one and the same semantic situation in different genres.

In the context of semantic syntax the situation of wine drinking (hereinafter referred to as SWD) belongs to "action" group of situations and is a social-physical action. The minimum model of the situation is as follows: subject predicate of physiological action - object: a person imbibes, for example: "I got acquainted with some foreigners. We enjoyed drinking vodka and biting liver sausages after" (in Russian: У меня появились знакомые иностранцы. Сидели до поздней ночи. Охотно пили водку, закусывая ливерной колбасой) (S.D. Dovlatov "Ours") (Babenko, 2002, p. 155).

SWD as denotation of the process of the same name, including consumption of strong alcoholic drinks and snacks, is aimed at "achieving a state of an alcohol intoxication" and is represented by the verb numb/to drink. This verb can be characterized as the main representative form of the analyzed situation. The verb numb/to drink can be represented by the context synonym - the verb sinumb/to drink off, for example: Nikanor Ivanovich poured himself a wineglassful of vodka, drank it off, speared three slices of herring with his fork" (in Russian: Никанор Иванович налил лафитничек водки, выпил, налил второй, выпил, подхватил на вилку три куска селедки...) (M.A. Bulgakov “The Master and Margarita").

The verb numb/to drink is the central linguistic form, the key verb, but the language has a series of related verbs.

Linguistic materials for research analysis were the statements of various grammatical and semantic size, including one or several predicates that describe SWD. For instance, the simplest example of linguistic reflection of reality is the cited fragment: "He drank a shot glass of vodka" (Он выпил рюмку водки). In the Russian language more complex poly-proposition look at
SWD is also possible: in some cases SWD seems complicated and acquires details thanks to the situational component of emotional nature. In this case, the semantic formula is - Subject (1) drinks + (2) pours out one's heart. See the example of 2-propositional SWD representation in the following text: "Got frozen? asked Bobrov. - Do you want something to drink?.. (1) No matter how angry is the Russian, if you offer him to drink, he gets kinder anon... (2) At the table Lesha told $<\ldots>$ And I remembered one old story" (in Russian: - Замерзли? - спросил Бобров. Хотите выпить?. (1) Как бы ни злился российский человек, предложи ему выпить, и он тотчас добреет... (2) За столом Леша рассказал <..> Тут я вспомнил одну давнюю историю) (S.D. Dovlatov “Ours").

SWD can also be represented through predicates of physical perception, for instance: "His hand twitching, Styopa brought the glass to his lips, while the stranger swallowed the contents of his glass at one gulp". (in Russian: Прыгающей рукой поднес Степа стопку к устам, а незнакомеи одним духом проглотил содержимое своей стопки) (M.A. Bulgakov "The Master and Margarita"). The author describes the visual perception, and the very process of wine drinking is recorded by the predicates of physical perception, such as swallowed, at one gulp / проглотить, сделать глоток, while the subjects of the process are the characters of the novel.

Moreover, SWD is often complicated by other propositional fragments: 1) (1) alcohol consumption proposition + (2) proposition of qualitative characteristics of the subject: "Such people are rare, we have to love them... (1) $\mathrm{He}$ drinks, (2) at times he's coarse - well does it matter? (2) Talented people in Russia are so rare, they can't be perfect $<\ldots>$ (in Russian: Такие люди редки, их нужно любить... (1) $\underline{\mathrm{OH}}$ nьет, (2) бывает грубоват, но что за беда? 
(2) Талантливый человек в России не может быть чистеньким (...)) (A.P. Chekhov "Uncle Vanya"). 2) (1) alcohol consumption proposition + (2) causal action proposition, for example: "And Mr Cook , he continued, last Sunday (1) drank up a bottle of vodka in the restaurant, and (2) crawled home sozzled" (in Russian: - A мистер Кук, - продолжал он, - в прочлое воскресенье (1) вылакал в трактире четверть водки и (2) приполз домой на бровях) (V.Ya. Shishkov “Ugryum River").

The authors of the paper do not exclude other options of propositional complication of the original model. In this context interesting are the situations describing the various states of intoxication. There we deal with manifestation of the factual proposition, where the following actants are represented: Fact - Subject of Fact (Sf); Perception - Subject of Perception (Sp); Manifestant (Osetrova, 2012). Regarding SWD, it looks like this: "Prokhor, as usual, was pieeyed and reeked of cheap cologne" (in Russian: Прохор, по обыкновению, был под мухой - от него так и разило дешевым одеколоном) (F.A Abramov "Wooden Horses"), where Fact is - pieeyed / был под мухой; Sf and Sp are - Prokhor / Прохор; Perception of Manifestant is - reeked of cheap cologne / от него так и разило дешевым одеколоном;

Typical SWD actants in this situation are subject, object, comitative, instrumentative and causative, circonstants - temporative and locative. The different types of texts have different sets of actants - they depend on the text in size and nature. In fiction this set is actually determined by the author's intention.

Having expressed a number of general linguistic ideas that became the basis for the analysis we made, let us continue to study a specific text material.

The actant component of SWD proposition in the anecdotes is the subject of alcohol drinking: a person, an animal, an object, a fantastic character. Human as a character of the humorous stories has the following characteristics: sex, marital status, kinship, nationality, occupation, the amount of alcohol drunk. That is why men more often than women are the characters. Regarding the amount of alcohol drunk the characters are: a teetotaler; a boozy person (drinks on holidays or special occasions); a boozer / a bukharchik (drinks more than a boozy person); a drunk / a drunkard / a dypso (abuse of alcohol), an alcoholic / an alky (sick people suffering from alcoholism).

There are also anecdotes about drinking animals: a wolf, a bear, a rabbit, a mouse, a frog, etc. The fairy-tale characters are represented by Baba-Yaga, Ivan the Fool, and Ilya Muromets.

The members of ethnic groups in anecdotes are following: Russian, Jewish, Scottish, French and English.

According to the professional group belonging surgeons, mechanics, hunters, soldiers and priests drink the most.

In the anecdotes about situation of alcohol drinking in addition to the main subject (actor) there is another minor subject (counter-actor). The minor subject is an actant of subjective type; this is a person interacting with another subject in the parallel relationship; the main subject and the minor subject perform oppositely directed actions (Shmeleva, 1988).

The role played by the minor subject is one of an opponent of drunkenness, in anecdotes this character is represented by a wife (or/and by a mother-in-law), for instance: "On the street there is a drunken man, who enters his yard. He sees a cuckoo sitting in the bushes. He asks, 'Cuckoo, cuckoo, how many years of life do I have?' Then the wife pops out of the window: Five-seven seconds... until I find an iron" (in Russian: Идеm пьяный мужик по уличе и заходит к себе во двор. Видит, в кустах сидит кукушка. Он говорит:-Кукушка, кукушка. Сколькомнелет 
осталось жить? Тут из окна высовывается жена: - Пять-семь секунд... пока я утюг не намла).

The subject can also be characterized by the amount of the alcohol that the person can drink alone, but more often the person drinks in the company, and the number of companions is classical - three people: "Two people met and started to search for the third to drink. - Tell me, do people drink in Africa, too? - Yeah. - Do they drink as we do? Knock off the bottle between three of them? - Yes, but only two people drink, the third is for the chaser" (in Russian: Встретились двое и стали искать третьего, чтобы выпить. - Скажи, а в Африке тоже пьют? - Пьют. - А как, по-нашенски? Тоже на троих соображают? - Да, только двое пьют, а третьим закусывают). Why there are three people? Because it is funnier and more economical. The researchers note that collectivity of SWD has a long tradition: "The more visitors and people who drink with them, the better, the more satisfaction he gets" (Stepanov, 2001).

It is easy to guess that the object of SWD in a Russian anecdote is vodka.

In the anecdote vodka has two characteristics: good and very good, it also can be represented metonymically -a half-liter a (halfliter bottle), a quarter-liter bottle, a small bottle of $125 \mathrm{ml}$. The second place is for beer, the third is for cognac, champagne and wine. Among the drinks you can also find ethyl alcohol, homedistilled vodka, rum, cologne and windscreen wiper. The choice of the drinks depends on the taste preferences (for example, the hussars in the anecdote drink only champagne) or on the social (material) status: "At the wine counter an elegant lady chooses white wine for salmon, red for venison on spit, cognac for coffee, etc. When, finally, she was up, a man standing behind furiously demanded: And for me a halfliter Kaluga vodka. For capelin in tomato sauce". (in Russian: У винного прилавка шикарная дама выбирает белое вино $к$ лососине, красное - к оленине на вертеле, коньяк - к кофе и т.п. Когда, наконец, она закруглилась, стоящий сзади мужчина с остервенением потребовал: - А мне пол-литру калужского разлива. Кмойве в томате.)

The instruments for drinking in SWD are also quite diverse. People drink vodka straight from the bottle (i.e., without any glassware, bottles), from the glasses, the goblets and the wine glasses, the shot glasses, although the drinking vessels are well represented in the literature

The time of drinking dose not really matter. Typically, the time characteristic concerns the time of day or on other actions, such as: "a) A man goes in the morning in the bus and shakes; b) Dad, banya is getting ready. Will you drink out a shot glass now or after banya?" (in Russian: а) Едет утром в троллейбусе мужик и его качает; б) - Папаня, баня уже топится. Bbl сейчас выкушаете стопочку или после бани?)

The location can also be anywhere - the one thing that amazes is the choice of places and breadth of this choice: street, public places, including playgrounds, means of transport (a plane, a train, a bus, a taxi and a car). In the anecdote the street means any place outside the home accommodation: a haystack; under a mighty oak; a place for hunting, fishing, mowing, building; a street itself. The public places are conventionally divided into two groups: a) those intended for the alcohol drinking (restaurants, taverns, bars, pubs) and b) those where alcohol drinking is prohibited (railway stations, cinemas, etc.). Accommodations are houses, apartments, where the character's kitchen plays the role of the special locus, or the place might be represented very broadly - someone is visiting another person.

We can say that in the anecdote Russian people drink everywhere (another look at the 
anecdote and its role is presented in another paper (Tarasenko, 2012).

In the next stage of the analysis we will consider fiction - plays by A. P. Chekhov.

The subjective representation of SWD in A. P. Chekhov's plays is detailed as follows, agents are main characters: mainly nobles and officials at the age from 20 years and older.

In A.P. Chekhov's plays both men and women drink (in "Uncle Vanya" - Sonya and Elena Andreevna, in "The Three Sisters" Masha). Note that in the anecdote there are no drinking women; this fact reflects the male point of the view on this social phenomenon, namely, women should not drink. The literary text reconstructs real life, therefore unlike the anecdotes women do drink in fiction. Instead of playing the role of condemning minor subjects (counter-actors), opponents of drunkenness men act as empathizing and understanding co-actors. A co-actor is a person of subjective type, not alone and being related with others in a joint activity, cooperation (Shmeleva, 1988, p. 46), as Trigorin or Sorin in "The Seagull": MASHA: To love without hope... to spend whole years waiting for something... But when I marry, there'll be no more of that, new cares will stifle the old. Anyhow, it will be a change... Shall we repeat? TRIGORIN: Isn't it too much? MASHA: So (pouring shots)...Don't look at me like that. Women drink more often than you imagine. Only a few drink openly, as I do, the majority drink in secret...Yes, and everybody vodka or cognac. (clanging her glass) Good luck! You're a very unassuming person, I'm sorry to be parting from you...(drinking) (in Russian: Маша. Любить безнадежно, иелые годы ждать чего-то... А как выйду замуж, будет уже не до любви, новые заботы заглушат все старое. И всетаки, знаете ли, перемена. Не повторить ли нам? Тригорин. $A$ не много ли будет? Маша. $H y$, вот! (наливает по рюмке.) Bbl не смотрите на меня так. Женщины пьют чаще, чем вы думаете. Меньшинство пьет открыто, как я, а большинство тайно. Да. И все водку или коньяк. (Чокается.) Желаю вам! Bbl человек простой, жалко с вами расставаться. Пьют). (A.P. Chekov “The Seagull”).

As in the anecdote, the female characters, as a rule, condemn drunkenness, for example, Sonya and Elena Andreevna in "Uncle Vanya", Irina in "The Three Sisters".

The perception of wine drinking for male characters in A. P. Chekhov's play may be polar, like Astrov's in "Uncle Vanya" or Chebutikin's in "The Three Sisters".

The characters of A.P. Chekhov's plays, as a rule, drink not very much unlike the characters of anecdotes. The drinks' selection is following: vodka, wine, champagne, cognac and beer. Analysis of the material showed that the characters of the plays (the male characters) prefer two types of drinks -vodka and wine, the women prefer only wine.

If we talk about philological and literary approach we want to state that the champagne embodies the holiday celebration, so it is drunk at a wedding ("The Wedding"), at the time of the marriage proposal ("The Offer"), so the scene of the failed marriage proposal of Lopakhin is not so illogical as it may seem: "No champagne no marriage proposal" (Ivleva, 2001). Champagne is the marker of the life of idleness, so the main character in "The Cherry Orchard" characterized her husband the next way: "I married a man who made nothing but debts. My husband died because of champagne - he drank dreadfully" (A.P. Chekhov "The Cherry Orchard"). The researchers associated champagne with the theme of the end, unfulfilled lives, which we can see in "The Three Sisters" and "The Cherry Orchard" (Ivleva, 2001). The theorists of literature especially note beer, which appeared in the plays only once and in the unusual circumstances (in 
an impossible combination from the perspective of a connoisseur): "ARKADINA: The red wine and the beer for Boris Alexeevich goes right here on the table. We will play and drink". (in Russian: Аркадина. Красное вино и пиво для Бориса Алексеевича ставьте сюда, на стол. Mы будем играть и пить). (A.P. Chekhov “The Seagull”) (Ischuk-Fadeeva, 2001).

The place and the time of SWD in the dramatic text are not specifically actualized as it happens in the anecdote, because the time of SWD is specified by the time of the play as true fiction time and the place is real fiction space.

Thus, the center of denotative SWD happening in order to "achieve a state of intoxication" and "pour out one's heart" is a proposition represented in the Russian language by the verb numb/to drink. In addition, SWD can be complicated by a number of other propositions having different cause-and-effect relationships with the central one. In this case single proposition model of the situation is transformed into poly-propositional model with two or three phases.

Actants in this situation are subject, object, comitative, instrumentative and causative, circonstants are temporative and locative. The different types of texts have different sets of actants varying in quality and quantity, which depends on the text itself. We think that the anecdotes have the most comprehensive SWD, as for the quantity and quality of the represented predicates and actants. In the literary text the selection of predicates and members for wine drinking is defined by the author's intention (Tarasenko, 2015).

\section{References}

Babenko, L.G. (2002). Russkie glagol'nye predlozheniia: Eksperimental'nyi sintaksicheskii slovar' [Russian verbal clauses: Experimental syntactic dictionary]. Moscow, Flinta, Nauka, 464 p.

Dem'iankov, V.Z. (1983). “Sobytie” $v$ semantike, pragmatike $i v$ koordinatakh interpretatsii teksta ["Event" in semantics, pragmatics and coordinate interpretation of the text], In Izvestiia AN SSSR [News of the Academy of Sciences of the USSR. Ser. Literature and Language] 4 (42), 320-329.

Dem'iankov, V.Z. (2004). Semiotika sobytiinosti v SMI [Semiotics of eventness in the media], In Iazyk SMI kak ob"ekt mezhdistsiplinarnogo issledovaniia: uchebnoe posobie [The language of the media as an object of interdisciplinary research: textbook] 2, Moscow, Izd-vo Mosk. Un-ta (Moscow State University Press), 68-83.

Gak, V.G. (1972). Vyskazyvanie i situatsiia [The uttering and the situation], In Problemy strukturnoi lingvistiki [Problems of structural linguistics]. Moscow, Nauka, 349-372.

Ischuk-Fadeeva, N.I. "Dionisizm" chekhovskogo teatra ["Dionysianism" of Chekhov Theatre]. In Literaturnyi tekst: prolemy i metody issledovaniia - 8. Motiv vina v literature [Fiction text: problems and methods of research -8 . The motive of wine in the literature]. Tver, Izd-vo Tversk. Un-ta (Tver University Press), 45 -51.

Ivleva, T.G. (2001). Shampanskoe v khudozhestvennom mire A.P. Chekhova [Champagne in A.P. Chekhov's art world], In Literaturnyi tekst: prolemy i metody issledovaniia - 8. Motiv vina v literature [Fiction text: problems and methods of research - 8. The motive of wine in the literature]. Tver, Izd-vo Tversk. Un-ta (Tver University Press), 52 - 59.

Kon'kov, V.I., Neupokoeva, O.V. (2011). Funktsional'nye tipy rechi: uchebnoe posobie dlia studentov vysshego prof. obrazovaniia [Functional types of speech: textbook for university students]. Moscow, "Akademiia", 224 p. 
Nikolaeva, T.M. (1980). Sobytie kak kategoriia teksta i ego grammatologicheskie kharakterisitiki [Event as a category of text and its grammatical characteristics], In Struktura teksta [Structure of the text]. Moscow, Nauka,198-210.

Osetrova, E.V. (2012). Manifestatsiia fakta v russkom vyskazyvanii, ili Sobytie vyrazheniia: monografiia [The manifestation of the fact in the Russian statement, or Event of the expression]. Krasnoyarsk, Siberian Federal University, 275 p.

Shmeleva, T.V. (1988). Semanticheskii sintaksis: tekst lektsii [Semantic syntax: texts of lectures]. Krasnoyarsk, Krasnoyarsk State University, 53 p.

Stepanov, Iu.S. (2001). Vodka i P'ianstvo [Vodka and Alcoholism], In Konstanty: Slourar' russkoi kul'tury [Constants: Dictionary of Russian culture]. Moscow, Akademicheskii Proekt, 990 p.

Tarasenko, T.V. (2012). Metatekstovye funktsii anecdota $v$ mediatekste [Metatextual functions of the anecdote in the media texts]. In Vestnik KGPU im. V.P. Astaf'eva [Bulletin of KSPU named after V.P. Astafyev] 4, 324-327.

Tarasenko, T.V., Quero Gervilla, E. F. (2015). Everyday Culture in the Original Novel and its Translation (based on the translations of the Master and Margarita novel by M. A. Bulgakov into the Spanish language), In Journal of Siberian Federal University. Humanities \& Social Sciences, 12 (8), 2848-2860.

\title{
Семантическая ситуация и ее репрезентация
}

\section{в текстах разных жанров}

\author{
Т.В. Тарасенко \\ ${ }^{a}$ Сибирский государственный аэрокосмический университет \\ имени академика М.Ф. Решетнева \\ Россия, 660037, Красноярск, пр. Красноярский рабочий, 31

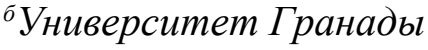 \\ Испания, 18010, Гранада, ул. Пуерта де лас Гранада
}

\footnotetext{
В данной статье анализируется семантическая ситуация и ее репрезентаџия в зависимости от типа текста, а именно текста городского фольклора - анекдота и художественного текста. В разных типах текстов набор актантов зависит от характера текста. B анекдотах ситуация винопития репрезентирована наиболее полно, на это указывает количество и качество репрезентируемых предикатов и актантов. В художественном тексте выбор предикатов и участников винопития задается авторским замыслом.
}

Ключевые слова: семантическая ситуация, анекдот, фольклорный текст, художественный текст, ситуация винопития, семантический синтаксис.

Научная специальность: 10.00.00 - филологические науки. 